\title{
ПРАЦЯ ЯК ФОРМА ЖИТТЕДІЯЛЬНОСТІ ОСОБИСТОСТІ ТА СУСПІЛЬСТВА
}

Стаття містить дослідження щуодо питання поняття праџі як суспільного явища і процесу. Розглядається поняття про працюю в соціальному значенні, виокремлено роль праці в житті кожної людини та суспільства. Проаналізовано основні фактори, які впливають на формування соціально-трудових відносин. Виокремлено функиії, завдяки яким реалізується сочіальна функція праці. Розкрито поняття «партнерство», основні причини конфліктних ситуацій та стадї їх розвитку, запропоновано иляхи подолання цуих ситуацій.

Наголошено, ше прачя - ие спосіб забезпечення існування людей. Протягом довгого часу відбувався перехід на сучасні автоматизації виробництва, а також інші види організаційних процесів. Це тягне за собою зміни змісту й саму сутність праці людини. При иьому праця виступає і як специфічний процес, який можливий тільки в спільній діяльності, в спілкуванні людей один з одним. Праця як проиес життєдіяльності є полем суб'єктивнооб'єктивних відносин. Крім того, ступінь напруженості включення індивіда в трудовий прочес варіюється в широкому діапазоні від формальної участі до активної зацікавленості. Також прачя виступає одним із факторів розвитку особистості, оскільки є сферою самовираження, самоствердження, самореалізації. Механічна праця людини в значному обсязі замінена комп'ютерними технологіями. Але реалії сьогодення внесли свої корективи у всі сфери життєдіяльності суспільства. Нині більшість людей працює, так би мовити, "дистанційно», ице тягне за собою зміни, які по-новому формують відносини між прачівником та роботодавием, колективом, але конфліктні ситуації не є вичерпаними. Тому соиіологія праці як спеціальна область соиіологічної теорії потребує того, щуоб в ї̈ осмисленні, по-перше, був підвищений рівень теоретичного узагальнення, щуоб вона не виглядала як набір актуальних, важливих, але не впорядкованих логікою соиіальних проблем, по-друге, проведений критичний відбір того кращого, щчо накопичено у вітчизняній практиці вирішення соціальних завдань виробництва, щчо стосуються всього спектра трудової діяльності людей.

Ключові слова: соціальні зміни, праця, партнерство, працівник, конфлікт, функиії.

Tetyana MELENTYEVA, orcid.org/0000-0001-8876-3624

Candidate of Philosophical Sciences,

Associate Professor at the Department of Philosophy and Sociology

National University of Pharmacy

(Kharkiv, Ukraine) Vjbcttdf27.5@gmail.com

\section{LABOR AS A FORM OF INDIVIDUAL AND SOCIAL ACTIVITY}

The article is devoted to the notion of labor as a social phenomenon and process. The attention is paid to the notion of labor in social meaning, the role of labor in life of an individual and society. The main factors influence on the formation of social and labor contacts. The functions realizing the social functions of labor are highlighted in the article. The notion of partnership, main reasons of conflicts, stages of its development and ways of solution are disclosed in the article.

It is emphasized that labor is a way to provide human existence. For a long time it was a transition to modern production automation and other kinds of organizational processes. It entails changes in the content and essence of human labor. In particular, work as a process of life is a field of subjective-objective relations. In addition, the degree of intensity of an individual's involvement in the labor process varies widely from formal participation in active interest. Also, work is one of the factors of personality development, as it is a sphere of self-expression, self-affirmation, self-realization. Mechanical labor of an individual is significantly replaced by IT. Reality introduced its correctives into all the branches of human activity. Many people today work in a distance way, the fact that leads to changes in the relationship between employee and employer, in the companies, but conflicts are not overcame. That's why sociology of labor as a special branch of sociological theory first of all needs a higher level of theoretical generalization not to be as a set of important but illogical social problems. Second, it should be made a critical selection of the best things that have been accumulated in the domestic practice of solving social problems of production, relating to the full range of human activities.

Key words: social changes, labor, partnership, worker, conflict, functions. 
Постановка проблеми. Нині у світі відбуваються корінні зміни в усіх галузях. I це пов'язано не тільки з політикою уряду, а й викликом сучасних подій. Тенденцією останнього часу був і $є$ перехід суспільства на нові відносини у сфері праці. В умовах «пандемії, яка охопила весь світ» повністю змінюються умови праці, вимоги, потреби, ресурси, відносини між роботодавцем та робітником, відбувається впровадження роботи дистанційно, тому вивчення цієї теми $є$ досить актуальним. Своєю чергою соціологія праці - це галузь соціологічного знання, предметом вивчення якої $є$ праця як суспільне явище, а також ті суспільні відносини, в які вступають учасники трудового процесу. Також процес праці включає в себе діяльність людини, або саму працю, предмет праці, тобто то, на що спрямована ця діяльність, і знаряддя виробництва, якими людина впливає на цей предмет.

Аналіз досліджень. Питання вивчення праці як соціального явища вивчають такі дослідники, як В. Судаков, А. Ноур, С. Кравцов, В. Тихонович, М. Ходоровськая, Г. Чепурко, І. Лікарчук, Т. Петровська, К. Самойлик, О. Семченко, С. Хутка, А. Чабан.

Мета статті - аргументувати наукову значущість соціологічних досліджень соціально-інтегративної сутностіпраців контексті соціологічного розуміння праці як соціального явища і процесу.

Об'єктом соціології виступає праця як суспільне явище і процес. Праця є найважливішою сферою діяльності людей. Це процес, який відбувається між людиною і природою, процес, в якому людина своєю власною діяльністю опосередковує, регулює і контролює обмін речовин між собою і природою.

Праця - головний фактор відтворення суспільства як цілісної системи, специфічний спосіб людського буття. У праці найбільш повно формується і виявляється особистість людини. Усі види людської діяльності (спорт, робота, гра, навчання) історично розвивалися на основі трудової діяльності і містять елементи останньої.

Зміст праці - це соціально-технологічна характеристика праці, яка враховує розподіл виробничої діяльності за галузями, види трудових операцій, різноманіття функцій, фізичну та інтелектуальниу напруга.

Характер праці відображає соціально-економічну специфіку праці, закріпленість робітників за різноманітними видами трудової діяльності (фізичної або розумової, аграрної або індустріальної, організаційної або виконавчої, простої або складної, творчої або рутинної). До умов праці належать, 3 одного боку, соціально-економічні умови, наприклад, тривалість робочого дня і трудового року, оплата праці, вимоги до загальноосвітньої і спеціальної підготовки робітників і т.п. Праця - основа функціонування та розвитку будьякого людського суспільства, двигун соціального прогресу, природна потреба, без якої не було б можливим людське життя.

Соціальна сутність праці реалізується в сукупності іiі соціальних функцій.

Функиіястворенняматеріальнихідуховнихблаг, суспільного багатства полягає у створенні благ i можливостей для задоволення людських потреб.

Функиія бути основою суспільства і суспільного устрою. Праця набуває суспільну форму, стає основою суспільних відносин i, перш за все, відносин власності. Тому розрізняють суспільства, засновані на громадській, приватній і змішаній власності на засоби виробництва.

Функиія міри розподілу суспільного багатства, міри споживання.

Функиія бути сферою самовираження, самоствердження і розвитку людини. Праця не тільки засіб задоволення потреб людини, а й життєво необхідний засіб самовираження, розкриття і реалізації творчих можливостей працівника.

Соціально-трудові відносини - відносини, які виникають між людьми в процесах, зумовлених трудовою діяльністю.

Фактори, що впливають на формування соціально-трудових відносин:

- соціальні положення різних груп у сфері праці;

- інтереси, поведінка груп і працівників.

- Суб'єктами соціально-трудових відносин є індивідууми чи соціальні групи.

Найманий працівник - це людина, яка уклала трудовий договір із представником підприємства, громадської організації або держави.

Роботодавець - це людина, яка наймає для виконання роботи одного або кількох працівників. Роботодавець може бути власником засобів виробництва або його представником.

Професійна спілка створюється для захисту економічних інтересів найманих працівників або осіб вільних професій у певній сфері діяльності.

Держава як суб'єкт соціально-трудових відносин в умовах ринкової економіки виступає в таких основних ролях: законодавець (розробляє правові основи соціально-трудових відносин), захисник прав громадян і організацій, роботодавець, посередник і арбітр у трудових спорах.

3 організаційних форм виділяють такі типи соціально-трудових відносин: патерналізм, партнерство, конкуренція, солідарність, субсидіарність, дискримінація і конфлікт. 
Патерналізм характеризується значною часткою регламентації соціально-трудових відносин із боку держави або керівництва підприємства.

Партнерство - система детально опрацьованих правових документів, відповідно до яких наймані працівники, підприємці і держава розглядаються як партнери в рішенні економічних і соціальних завдань.

Конкуренція між людьми або колективами також може сприяти досягненню синергетичного ефекту. Зокрема, досвід показує ефективність раціонально організованої конкуренції між конструкторськими колективами.

Солідарність передбачає спільну відповідальність і взаємну допомогу, засновану на спільності інтересів групи людей. Солідарність виявляють і члени спілок роботодавців, а також члени інших спілок.

Субсидіарність означає прагнення людини до особистої відповідальності задля досягнення своїх цілей і дії в процесі вирішення соціальнотрудових проблем.

Дискримінація - це засноване на свавіллі, незаконне обмеження прав суб'єктів соціально-трудових відносин. При дискримінації порушується принцип рівності можливостей на ринках праці.

Конфлікт $\epsilon$ крайнім вираженням протиріч у соціально-трудових відносинах. Найбільш явними формами трудових конфліктів $\epsilon$ трудові суперечки, страйки, масові звільнення (локаути).

Конфлікт виступає предметом дослідження багатьох наук, конфлікт розглядається як спір або зіткнення при досягненні певних цілей організації. Конфлікт - це протиріччя, що виникає між людьми в процесі тих чи інших питань. Виникненню конфлікту сприяють протиріччя, що зачіпають інтереси, статус, моральну гідність особистості або групи.

Раніше існувала точка зору, що конфлікти створюють напружені відносини в колективі, переключають увагу співробітників із безпосередньої роботи на «з'ясування стосунків». На сучасному етапі конфлікт не розглядається як деструктивний елемент. Конфлікт розглядається як один з органічних елементів організації, тому що дає змогу проявитися проблемі і сприяє іiї вирішенню.

Значний внесок у розвиток науки конфліктології зробив соціолог Р. Дарендорф (Дарендорф, 1994: 142-145). Він вважав, що кожне суспільство в будь-який момент часу пронизане неузгодженістю і конфліктом. У своїй концепції він виходить на поняття «життєві шанси», що позначає сукупність сприятливих економічних, соціальних i політичних можливостей для реалізації, що надаються індивіду тим становищем, яке він займає в суспільстві.

Але при цьому життєві шанси розподілені нерівномірно. Це зумовлено статусною структурою, і виникає нерівність, яка породжує різні конфлікти. Р. Дарендорф (Дарендорф, 1994: 146-147) вважає, що без конфліктів неможливий прогрес.

Т. Парсонс (Парсонс, 1996: 203-206) є представником напряму структурний функціоналізм i бачить одне 3 джерел виникнення конфліктів у руйнуванні традиційної системи цінностей, які, на його думку, виступають однією з основ соціальної стабільності суспільства.

Американський соціолог Л. Козер (Козер, 2000: 101) запропонував теорію конфліктного функціоналізму, в якій конфлікт розглядається як один із неминучих i необхідних двигунів соціального прогресу. На його думку, конфлікти необхідно вирішувати інституціоналізованим, законним шляхом, бо тільки таким чином він буде грати позитивну функціональну роль і сприяти підтримці соціальної рівноваги системи.

На думку К. Боулдінга (Боулдинг, 1969: 106-124), конфлікт - це ситуація, в якій сторони створюють несумісність своїх позицій, і кожна зі сторін прагне зайняти позицію, протилежну інтересам іншої. При цьому учасники конфлікту, усвідомлюючи своє протистояння, організовуються, щоб виробити спільну стратегію i тактику боротьби 3 противником.

Таким чином, конфлікт являє собою багатоаспектний, динамічний, що розвивається процес, який маєнетільки формипрояву, ай стадіїрозвитку:

- конфліктна ситуація;

- власне конфлікт;

- вирішення конфлікту.

Виникнення конфлікту є результатом взаємодії таких складників:

- ситуація (сукупність об'єктивних передумов, що провокують виникнення конфлікту);

- особистість учасника конфлікту (усвідомлення нею ситуації вступу в конфлікт);

- ставлення особистості до ситуації (наявність у неї мотивів вступу в конфлікт).

Існують такі причини виникнення конфліктів:

- невміння правильно сформулювати мету i постановку мети керівником;

- невміння враховувати індивідуальні особливості людей;

- інноваційні зміни в структурі організації зміна керівників, виникнення нових професійних груп, підвищення по службі, зниження зарплати;

- неправильне стимулювання підлеглих системою заохочення і покарання;

- неправильне ставлення до критики; 
- безтактність, а іноді й грубість із боку керівника.

Причиною конфлікту може стати і випадковий збіг обставин. Такий конфлікт важко передбачити, і в цьому разі керівнику доводиться оперативно діяти за результатами, а не щодо попередження конфлікту.

Існують різні класифікації конфліктів. Зупинимося на основних. Конфлікти діляться на природні й штучні. Природні конфлікти виникають самі собою в разі прояву значної невідповідності між чиїмось уявленням про колег, організації, діяльності організації і т. п. Штучні конфлікти створюються людьми для реалізації певних цілей, у тому числі для зняття накопиченого стресу.

Залежно від ступеня залучення в них співробітників конфлікти діляться на горизонтальні, вертикальні, змішані. У горизонтальні конфлікти залучені співробітники, які не перебувають у підпорядкуванні один одного. У вертикальних конфліктах залучені співробітники, що знаходяться в підпорядкуванні. Змішані конфлікти припускають залучення співробітників, які не перебувають у підпорядкуванні один одному, та й ті, що знаходяться в підпорядкуванні.

На основі соціально-психологічної типології виділяють такі види конфліктів: конфлікти комунікації, конфлікти влади й безвладдя, внутрішньоособистісний конфлікт, міжособистісний конфлікт, конфлікт між особистістю і групою, міжгруповий конфлікт.

Комунікаційний конфлікт виникає в разі відсутності зворотного зв'язку в організації.

Конфлікти влади і безвладдя виникають коли керівнику протистоїть опозиція, до якої примикає більшість працівників.

Конфлікт пов'язаний із пред'явленням людині суперечливих вимог щодо того, яким має бути результат його роботи.

Міжособистісний конфлікт найчастіше пов'язаний із боротьбою керівника за обмежені ресурси, капітал, робочу силу, час використання обладнання або схвалення проєкту.

Конфлікт між особистістю і групою проявляється, якщо очікування групи суперечать очікуванням окремої особистості.

Міжгрупові конфлікти можуть проявлятися в разі зіткнення профспілки й адміністрації, формальних і неформальних організацій.
Визначення керівником виду конфлікту дуже важливо для його вирішення. Виділяють такі способи виходу з конфлікту, засновані на безпосередніх діях керівника:

- переговори з опонентами - при досягненні компромісу може зникнути основа конфлікту;

- зміна предмета конфлікту, а значить, зміна ставлення до конфлікту;

- відокремлення суперечки між конфліктуючими сторонами від проблеми, яку потрібно вирішити, аналіз можливих шляхів вирішення проблеми і вибір кращого з них, прийнятного для всіх сторін конфлікту;

- створення ідеальних робочих місць;

- комплексний підхід до мінімізації конфліктних ситуацій.

Якщо основу конфлікту становлять об'єктивні умови, то його просте переривання без прийняття ефективних заходів щодо подолання причин може створити ще більш гостру ситуацію, бо після переривання конфлікту конфліктна ситуація зберігається.

Висновки. Таким чином, праця - це загальне суспільне явище. Це означає, що воно притаманне будь-яким суспільним системам, починаючи 3 примітивного суспільства і закінчуючи сучасним. Це явище визначає функціонування суспільства як безпосередньо, так і опосередковано через інші суспільні системи. Тому праця - це явище, що лежить в основі інших суспільних явищ. По-друге, основу праці становить соціально організована, усвідомлена і цілеспрямована людська діяльність. Однак праця трактується соціологією як поняття ширше, ніж діяльність. Праця - це інститут, який формується соціальним середовищем і водночас створює умови суспільного життя. Праця - це складна система суспільних відносин, пов'язаних з економічною, правовою, політичною та іншими системами. Це простір формування і передачі суспільної інформації та знань. Праця - це результат діяльності, оскільки в будь-якому зробленому суспільному продукті присутня праця людини. На це здатна тільки людина, тому говорять, що праця - виключно людська здатність. Під час праці, у взаємозв'язку між людьми обов'язково виникають конфліктні ситуації, які треба вирішувати, використовуючи запропоновані нами способи виходу з конфлікту. 


\section{СПИСОК ВИКОРИСТАНИХ ДЖЕРЕЛ}

1. Боулдинг К. Общая теория систем - скелет науки. Исследования по общей теории систем. Москва : Прогресс. 1969. $520 \mathrm{c}$.

2. Дарендорф Р. Элементы теории социального конфликта. Социс (Социологические исследования). 1994. № 5. C. 142-147.

3. Карташова Л. В. Организационное поведение : учеб. пособие. Москва : ИНФРА. 2006. 157 с.

4. Козер Л. А. Функции социального конфликта. Москва : Дом интеллектуальной книги Идея-пресс. 2000. 295 с.

5. Кравченко А. И. Социология управления : фундаментальный курс : учеб. пособие для студентов высших учебных заведений. 2-е изд., испр. и доп. Москва : Академический проект. 2005. 1136 с.

6. Парсонс Т. Система координат действия и общая теория систем действия культура, личность и место социальных систем. Американская социологическая мысль. Москва, 1996. 478 с.

7. Перепельчук Т. В. Соціологія праці : Навчальний посібник. Одеса : ОНЕУ. Ротапринт. 2011. 234 с.

8. Соціологія : навчальний посібник / за ред. О. В. Горпинич та ін. Київ : ДУТ. 2019. 235 с.

9. Ядов В. Стратегия социологического исследования. Москва : Академкнига, Добросвет. 2003. 596 с.

\section{REFERENCES}

1. Boulding K. Obshchaya teoriya sistem - skelet nauki. Issledovaniya po obshchej teorii sistem. [General systems theory is the skeleton of science. Research in General Systems Theory]. M. Progress. 1969. 520 p. [in Russian].

2. Darendorf R. Elementy teorii social'nogo konflikta. [Elements of the theory of social conflict]. Socis (Sociological Research). 1994. № 5. P. 142-147 [in Russian].

3. Kartashova L. V. Organizacionnoe povedenie. [Organizational behavior]. Study. allowance. M. INFRA. 2006.157 p. [in Russian].

4. Kozer L. A. Funkcii social'nogo konflikta. [Functions of social conflict]. Moscow : House of Intellectual Books IdeaPress. 2000. 295 p. [in Russian].

5. Kravchenko A. I. Sociologiya upravleniya [Sociology of management]. Fundamental course of study. Manual for students of higher educational institutions, 2nd ed., rev. and add. M. Academic project. 2005. 1136 p. [in Russian].

6. Parsons T. Sistema koordinat dejstviya i obshchaya teoriya sistem dejstviya kul'tura, lichnost' i mesto social'nyh sistem. [Action coordinate system and general theory of action systems culture, personality and place of social systems]. American Sociological Thought. M. 1996. 478 p. [in Russian].

7. Perepel'chuk T. V. Sociologiya praci. [Sociology of labor]. A textbook. Odessa : ONEU. Rotaprint. 2011.234 p. [in Ukrainian].

8. Sociologiya: navchal'nij posibnik. [Sociology]. A textbook / ed. O. V Gorpynych and others. Kyiv : DUT. 2019. 235 p. [in Ukrainian].

9. Yadov V. Strategiya sociologicheskogo issledovaniya. [Sociological research strategy]. M. Akademkniga. Goodness. 2003. 596 p. [in Russian]. 